\title{
Research on Motivation of Participating in Science and Technology Tourism
}

\author{
Yuwei Liu \\ Tourism Management, School of Management, Shanghai university, Shanghai, China \\ Email: catherine612@sina.cn
}

\begin{abstract}
After reading some of the literature on motivation and technology tourism, the author briefly expounds and summarizes the characteristics, development status and motivation of science and technology tourism. Through questionnaires and in-depth interviews, this paper studies the attitudes of tourists towards science and technology tourism, the types of science and technology tourism that they like, and the motivation of travelling. These motives indicate a difference between technology travelers and mass tourists. After the data was sorted and analyzed, some individual differences in these motives were found. The results show that there is no difference in subjects' attitudes toward science and technology tourism. The favorite form of tourism is "Natural Science and Ecological Tourism". This paper aims to provide some constructive opinions on the development and design of current travel agency technology tourism products through these research results.
\end{abstract}

Keywords: Science and technology tourism, motivation, individual differences.

\section{Introduction}

China's travel agency industry is scattered, weak, and poor, which needs to be transformed. The product of it is single; the market competition is fierce, but the product differentiation is not obvious. Travel agencies have gradually been replaced by the Internet, and consumers are more inclined to choose products that suit themselves and customize personalized products on the Internet.If a travel agency wants to take the lead in the fierce market competition, it should also transform from an intermediary role to content production and continuously develop new tourism products.

In recent years, a new form of tourism, science and technology tourism has emerged. At present, there are not many travel agencies that put their energy into this new type of tourism, so it is a good chance for most travel agencies. If a travel agency can make this kind of tourism product its own characteristics, it can stand out among many competitors.

Technology tourism sprouted in the 1930s and matured in the 1950s. At present, a relatively mature and perfect system has been formed in foreign countries. However, in China, in the mid-1990s, the concept of science and technology tourism was officially formed in China. However, in China, in the mid-1990s, the concept of science and technology tourism was officially formed in China. Although there are already some forms of technology tourism, such as visiting science and technology museums, observatories, weather stations, etc. or going to Sichuan, Tibet and other places to visit the glacier, in general, this special form of tourism is still only in the early stages, and there are still some problems in the direction of development. The Science and Technology Park's tourism products are of a single type, with limited limitations and lack of sufficient participation. It is difficult for visitors to make a deep impression after visiting, and they will not have the idea of going back again.

The promotion is not enough. Many tourists do not even know what science and technology tourism is, and have never heard of this form of tourism. Practitioners and local public have insufficient understanding of the value of scientific and technological resources, which has led to conflicts between resource possession and resource development. The current science and technology tourism is still in a stage of extensive development. Compared with traditional sightseeing tours, it cannot fully highlight its advantages of high technology content and strong participation. Existing technology tourism products are not much different from general tourism products or other tourism products.

The value of science and technology tourism lies in its intellectual value. Therefore, travel agency operators need to think about, how to explore the value of science and technology tourism, how to pass this 
value to consumers, how to better promote and plan such tourism activities, and how to transform from a seller to a producer. To solve these problems, we must understand people's motivation for science and technology tourism. Looking back at the previous travel literature, there are many studies on motivation, but few people study the motives of science and technology tourism. Travel motivation may be the same or different for different travel activities. Therefore, when emerging tourism products appear, it is particularly important to study tourism motives according to their characteristics.

In summary, we have studied what kind of forms of technology travel are more interesting to travelers? Are their attitudes toward science and technology tourism related to demographic characteristics? What is the main travel motivation? Is there a difference in motivation depending on age, occupation, income, etc.? Only by understanding the above problems can we plan tourism products for tourists' preferences, and obtain higher tourist satisfaction and loyalty, thus enhancing the core competitiveness of science and technology tourism activities.

\section{$2 \quad$ Literature Review}

Tourism motivation means that once a tourist has a potential unmet need, a response strategy designed to meet such needs will immediately emerge to achieve satisfactory results (Iso-Ahola, 1982).As an important area of tourism research, tourism motivation has been valued and paid attention by domestic and foreign tourism researchers (Juergen Groth, 1997; Lohn L Crompton, 1997; Metin Kozak, 2002; Zhang Hongmei, Lu Lin, 2005; Liu Xiao, 2008). Travel motivation has a significant impact on the choice of tourist destinations (Zhao Wei, Guan Hongzhi, Wang Wei), and it closely related to tourist revisit rate, tourist satisfaction, etc. (2013, Intanai Adchariya; 2013, Guo Anzhen, Huang Fucai; 2011, Mao Xiaogang, Song Jinping). Therefore, the research on tourism motivation has theoretical significance on tourism psychology and behavior, and also has practical guidance for destination development and tourism product design.

The theoretical study of motivation was introduced to the field of psychology by Woodworth in 1918. There are two widely used theoretical mechanisms of motivation. The theory of drive (Hull, 1942) argues that when the needs of an organism are not met, so-called internal drive stimuli are generated inside the organism, and then causes the reaction, and the final result of the reaction makes the need to be satisfied; Lewin's theory of expectation value argues that expectations of achieving goals determine behavior. When Tolman combines the theory of drive and the theory of expectation value, it forms a framework of push-pull theory that is widely recognized by scholars. He believes that motivation is divided into internal and external. The inner contains the emotion based on the drive, and the external contains the cognition.

The study of tourism motives in foreign countries can be traced back to the 1930s. R. glucksmann (1935) of Germany first studied tourism motives. Later, domestic and foreign scholars explored tourism motives in many aspects. Different scholars have different classifications of travel motivation. Different scholars have different classifications of travel motivation. Some scholars have theoretically summarized motivations. For example, Japanese scholar Tanaka Hiroshi proposed four kinds of tourism motives: mood motivation, physical motivation, spiritual motivation and economic motives; Robert Mackintosh proposed physical health, culture, communication, prestige and status; some scholars have also proposed a classification theory framework for studying tourism motivation, such as push-pull theory, escape-seeking theory, and Maslow's hierarchy of needs. Dann (1981) applied the push-pull framework to the analysis of tourism motivation. The push factor made tourists have the desire to travel, while the pull factor had a great influence on the choice of destination, namely the attraction of destination. Escape-seeking theory (Iso-Ahola) refers to the desire to leave the everyday environment and the desire to obtain an intrinsic psychological reward through the comparison of environmental tourism. In addition, Maslow's hierarchy of needs is also widely used in the study of tourism motivation. The theory states that human needs are divided into physiological needs, security needs, social needs, respect for needs and self-fulfilling needs.

Current scholars have empirically studied motivation with specific destinations as examples (Terry Lam, 1999; Samuel Sengseop Kim, Chong-Ki Lee, David B Klenosky, 2003; Metin Kozak, 2002; Intanai Adchariya, 2013). The conclusions obtained by the motivational research institutes targeting tourist destinations are mostly in line with the push-pull framework. Thrust is a person's own psychological factors (such as: relaxation, prestige, dreams, etc.), and tension is related to the characteristics of the destination (such as: beautiful scenery, unique attractions, human resources, etc.). These conclusions are 
important for marketing of destinations.

Some scholars have also studied the motivation of a certain kind of tourism activities (Jennifer Francioni Kraftchick; Erick T. Byrdb; Bonnie Canziani; Nancy J. Gladwell; Chen Nan, Qiao Guanghui; Wang He, 2010; Zhang Tao, 2012). As far as the current literature is concerned, the results of empirical research on a particular tourism activity are also in line with the push-pull framework. The thrust factor has certain similarities with the destination research, such as leisure and relaxation, and pursuit of prestige. However, from the perspective of the tension factor, the active tourists are more attracted by the characteristics of the activity itself, such as the experience of the event, specific products, and supporting services. However, due to the current small number of studies on different tourism activities, we still cannot determine whether some of the emerging forms of tourism are accepted by domestic tourists and what their specific motives are.

At present, the tourism industry has moved from the era of mass tourism to holiday tourism, and will inevitably move to a higher-end, more niche form of tourism. With the development of tourism and the improvement of tourists' tastes, the status of traditional sightseeing and holiday tourism will gradually be replaced by personalized tourism and special tourism (Su Liya). As an emerging form of tourism, science and technology tourism is heating up on a global scale. As a sunrise industry developed by the government, it will surely develop faster and better in the new century (Li Tingyong). As a product developer and designer, travel agencies should seize this opportunity to create a new kind of tourism activity, from media roles to content production, bringing visitors a new travel experience. This is the trend of the development of the tourism industry and a new stage in the development of travel agencies. However, the current research on science and technology tourism mainly focuses on the basic theories of science and technology tourism and tourism development strategies (Lin Miaohua, Tao Zhuomin, Sha Run), and lacks special research on the motivation of science and technology tourism. Peace (1995) argues that different empirical studies lead to a diverse portfolio of motivational projects due to differences in the target audience, research focus, and research.

Studying the essential motivation of tourists participating in science and technology tourism can make up for this deficiency to a certain extent, provide a case for the theoretical study of the motivation of tourism activities, and understand the needs of customers, providing feasible practical guidance for the further development of science and technology tourism.

\section{Data Acquisition and Research Methods}

\subsection{Preparation}

In the design of the questionnaire, in order to deepen the understanding of science and technology tourism, broaden the ideas and enrich the motivation of the second part of the questionnaire, we first conducted in-depth interviews. In-depth interviews with a professional teacher, a professional travel agency staff, and a number of students and office workers. After sorting out the interviews, some high-frequency keywords were extracted as the initial options for technology tourism motivations.

\subsection{Questionnaire Design}

The questionnaire consists of three parts: The first part is to study the attitude of subjects to science and technology tourism and which type of technology tourism is the most popular. The second part is to identify the specific travel motivation of tourists. According to the motivation factors mentioned in the in-depth interviews, and referring to the motivation factors mentioned in more than ten domestic and foreign related motivation researches, a total of 30 options were designed. The third part is the respondent's personal information form, including gender, age, education, occupation, and income.

\subsection{Distribution and Collection of Questionnaires}

After designing the questionnaire, I first found a dozen students from different majors and conducted a pilot test. I conducted in-depth discussions with the subjects and recorded the time to complete the questionnaire, revised the unclear or illogical meaning of the questionnaire, and revised the relevant 
indicators to prepare for the formal investigation. A formal sample survey was conducted on the platform for professional questionnaires on September 20, 2017 (due to time and space constraints, the current method of issuing questionnaires is the most feasible method I can take). As of October 4, 2017, a total of 309 subjects completed and submitted the questionnaires. After examining the source and the time of the test, and excluding the less authentic samples, a total of 281 valid samples were finally used.

\subsection{Data Analysis}

All data obtained was analyzed using the software Spss19.0.0 version. The personal information of the subjects was sorted out and their attitudes toward science and technology tourism were tested. By calculating the mean and ranking of each motivation, it is used to understand which motivations the subjects are more concerned about. According to the personal characteristics of the subjects, non-parametric tests were conducted on each motivation.

\section{Research Results}

Table 1. Demographics of subjects $(\mathrm{N}=281)$

\begin{tabular}{|c|c|c|}
\hline Item & Percentage $(\%)$ & Quantity \\
\hline \multicolumn{3}{|l|}{ Gender } \\
\hline male & 43.8 & 123 \\
\hline female & 56.2 & 158 \\
\hline \multicolumn{3}{|l|}{ Age } \\
\hline 19 years old and below & 7.1 & 20 \\
\hline 20 29 years old & 81.1 & 228 \\
\hline 30 39 years old & 3.9 & 11 \\
\hline 40 49 years old & 6.4 & 18 \\
\hline 50 years old and above & 1.4 & 4 \\
\hline \multicolumn{3}{|l|}{ Monthly income } \\
\hline Less than 3,000 yuan & 17.1 & 48 \\
\hline 3000 5000 yuan & 13.2 & 37 \\
\hline 5000 8000 yuan & 7.5 & 21 \\
\hline More than 8000 yuan & 6.8 & 19 \\
\hline No income & 55.5 & 156 \\
\hline \multicolumn{3}{|l|}{ Education } \\
\hline Junior high school and below & 0.7 & 2 \\
\hline High school and secondary school & 3.2 & 9 \\
\hline College & 16.0 & 45 \\
\hline Bachelor & 71.9 & 202 \\
\hline Master & 6.0 & 17 \\
\hline Doctor & 2.1 & 6 \\
\hline \multicolumn{3}{|l|}{ Occupations } \\
\hline Merchant & 5.7 & 16 \\
\hline Civil servant & 1.8 & 5 \\
\hline Teacher & 5.3 & 15 \\
\hline Senior white-collar worker & 2.5 & 7 \\
\hline General white-collar worker & 11.4 & 32 \\
\hline Military & 0.7 & 2 \\
\hline Blue-collar workers & 0.4 & 1 \\
\hline Retired employees & 0.0 & 0 \\
\hline Students & 66.5 & 187 \\
\hline Unemployed & 1.8 & 5 \\
\hline Scientific researchers & 1.4 & 4 \\
\hline Others & 2.5 & 7 \\
\hline
\end{tabular}




\subsection{Sample Statistics}

The demographic characteristics of the subjects in this study are shown in Table 1. In terms of gender, there were more female subjects, accounting for $56.2 \%$ (158) of all subjects, and male subjects accounting for $43.8 \%$ (123).In terms of age, subjects with the highest number of 20-29 years old accounted for $80 \%$ (228) or more, and those with 50 years old and above had the least subjects, accounting for $1.4 \%$ of all subjects (4). In terms of income, the largest number of people without income reached $55.5 \%$ (156), and the subjects with monthly income above 8,000 were the least, accounting for only $6.8 \%$ (19). According to the level of education, most of the subjects are undergraduate, and there are very few junior high school and below. In terms of occupation, students accounted for the most, accounting for $66.5 \%$ (187).

\subsection{Respondent's Attitude Difference}

$80.8 \%$ (227) of the subjects expressed their preference for technology tourism, and only a small percentage $(19.2 \%)$ of the subjects did not like science and technology travel. After a chi-square test on the question of whether different subjects have different attitudes toward science and technology tourism, I found that subjects' attitudes with different genders, ages, education, occupations, and incomes have no significant difference (gender chi-square $=0.157$, age chi-square $=0.310$, academic chi-square $=0.853$, professional chi-square $=0.666$, income chi-square $=0.136)$. Table 2 gives the attitudes of subjects with different genders. The specific data showing the attitudes of subjects of different ages, education, income, etc. are not mentioned here.

Table 2. Attitudes of subjects with different genders for science and technology tourism $(\mathrm{N}=281$, Sig. $=0.157)$

\begin{tabular}{cccc}
\hline & Male & Female & Total \\
\hline Like & $104(45.8 \%)$ & $123(54.2 \%)$ & $227(80.8 \%)$ \\
Dislike & $19(35.2 \%)$ & $35(64.8 \%)$ & $54(19.2 \%)$ \\
Total & $123(43.8 \%)$ & $158(56.2 \%)$ & $281(100 \%)$ \\
\hline
\end{tabular}

\subsection{Types of Technology Travel That Subjects Like}

Among the five types of science and technology travel, according to the number of selected times, the subjects' favorite is "natural science and ecological tour", which is 199 times (32.10\%), followed by "technology theme park tour", 179 times ( $28.87 \%$ ), and the most inattentive to subjects was "industrial tour", only 52 times (8.39\%), as shown in Table 3 .

Table 3. Types of technology tourism that subjects like

\begin{tabular}{lcc}
\hline \multicolumn{1}{c}{ Types } & Like (Quantity) & Percentage (\%) \\
\hline Natural Science and Ecological Tour & 199 & 32.10 \\
Scientific Site Tour & 87 & 14.03 \\
Technology Theme Park Tour & 179 & 28.87 \\
Technology Exhibition Tour & 103 & 16.61 \\
Industrial Tour & 52 & 8.39 \\
\multicolumn{1}{c}{ Total } & 620 & 100 \\
\hline
\end{tabular}

\subsection{Respondent's Motivation}

After sorting the mean values of the motivations for participating in science and technology tourism, the results show that among all the motivations given, the most significant motivation is to "expand the horizons" with an average of 3.96. The least important thing is to "follow others", whose average value is only 2.75; and the specific results are shown in Table 4. 
Table 4. Mean ranking travelling motivations $(\mathrm{N}=281)$

\begin{tabular}{|c|c|c|}
\hline Travelling motivations & Mean & Standard deviation \\
\hline 3. Expand the horizons & $3.96^{* *}$ & 1.058 \\
\hline 20.Experience a different felling from everyday life & 3.79 & 1.025 \\
\hline 6.Share experience after the tour & 3.78 & 0.983 \\
\hline 27.Add new experiences and form new ideas & 3.75 & 0.986 \\
\hline 13.Try new things & 3.73 & 1.023 \\
\hline 17.Satisfy your own curiosity & 3.72 & 1.011 \\
\hline 1.Individual interests & 3.72 & 1.132 \\
\hline 19.While studying and working, while playing, not boring & 3.68 & 1.047 \\
\hline 30.Satisfy the spiritual needs of seeking new and different ideas & 3.68 & 0.985 \\
\hline 18. Novelty of the tourism products & 3.63 & 1.031 \\
\hline 16.Education for children in science and technology & 3.62 & 1.128 \\
\hline 26.Learn natural science knowledge while enjoying life & 3.62 & 0.979 \\
\hline 22.Accompany friends or family interested in technology & 3.59 & 1.018 \\
\hline 9.Seeking excitement & 3.57 & 1.094 \\
\hline 14.Revisit & 3.53 & 1.032 \\
\hline 23.Want to understand the future direction of technology & 3.50 & 1.053 \\
\hline 25.Develop a deeper understanding of technology and culture & 3.47 & 1.042 \\
\hline 2.Tourism destinations are famous & 3.44 & 1.061 \\
\hline 8.Recommended by others & 3.42 & 0.903 \\
\hline 24.Haven't been there, so I want to go & 3.42 & 1.060 \\
\hline 29. Communications between the same industry & 3.27 & 1.042 \\
\hline 10.Investigate advanced technology & 3.25 & 1.126 \\
\hline 5.Meet new people & 3.21 & 1.067 \\
\hline 12.Company or school organized travel & 3.19 & 1.087 \\
\hline 28. Recognized by the society as a high taste & 3.15 & 1.041 \\
\hline 4.Attracted by advertising & 3.11 & 1.015 \\
\hline 11.Related to the field of your own research & 2.93 & 1.183 \\
\hline 15.show off when communicating with others & 2.90 & 1.103 \\
\hline 21.Work requirements & 2.89 & 1.090 \\
\hline 7.Follow others & $2.75^{*}$ & 0.989 \\
\hline
\end{tabular}

Remark. The Likert scale is used; "**" means the maximum value, and "*" means the minimum value.

\subsection{Differences in Motivation between Different Subjects}

\subsubsection{Differences in motivation between subjects with different ages}

In order to understand the different motives of different types of tourists, we conducted a non-parametric test of motivation. The results show that tourists with different monthly incomes only show differences in the motivation "Want to understand the future direction of technology" (sig=0.027). There are differences in 11 motivations among tourists of different ages, as shown in Table 5.

\subsubsection{Differences in motivation between subjects with different academic background}

Tourists with different academic background have differences in six motives, "Share experience after the tour", "Recommended by others", "Seeking excitement", "Related to the field of your own research", "Try new things" and "Satisfy your own curiosity", as shown in Table 6.

\subsubsection{Differences in motivation between subjects from different occupations}

Subjects from different occupations showed significant differences in the four motivations shown in Table 7 . 
Table 5. Differences in motivation between different age groups

\begin{tabular}{|c|c|c|c|c|c|c|}
\hline Motivations & $\begin{array}{c}19 \text { years old } \\
\text { and below } \\
(\text { mean })\end{array}$ & $\begin{array}{c}20 \sim 29 \\
\text { years old } \\
(\text { mean })\end{array}$ & $\begin{array}{c}30 \sim 39 \\
\text { years old } \\
(\text { mean })\end{array}$ & $\begin{array}{c}40 \sim 49 \\
\text { years old } \\
(\text { mean })\end{array}$ & $\begin{array}{c}50 \text { years old } \\
\text { and above } \\
(\text { mean })\end{array}$ & Sig. \\
\hline 2.Tourism destinations are famous & $2.45^{\text {bcdef }}$ & $3.56^{\mathrm{a}}$ & $3.27^{\text {acd }}$ & $3.17^{\text {acde }}$ & $3.50^{\mathrm{ac}}$ & $0.001^{* *}$ \\
\hline 8.Recommended by others & 2.85 & 3.50 & 3.64 & 3.17 & 2.50 & $0.016^{*}$ \\
\hline 9.Seeking excitement & 3.20 & 3.68 & 3.27 & 2.94 & 3.00 & $0.031^{*}$ \\
\hline 10.Investigate advanced technology & 2.55 & 3.34 & 3.18 & 2.83 & 3.75 & $0.017^{*}$ \\
\hline 12.Company or school organized travel & $2.35^{\text {bdefg }}$ & $3.25^{\mathrm{ac}}$ & $3.18^{\text {ace }}$ & $3.44^{\mathrm{ac}}$ & $3.00^{\text {acef }}$ & $0.005^{* *}$ \\
\hline $\begin{array}{l}\text { 16.Education for children in science and } \\
\text { technology }\end{array}$ & $2.75^{\text {bdefg }}$ & $3.66^{\mathrm{ac}}$ & $3.64^{\text {ace }}$ & $4.22^{\mathrm{a}}$ & $3.25^{\text {acef }}$ & $0.006^{* *}$ \\
\hline 17.Satisfy your own curiosity & 3.21 & 3.82 & 3.36 & 3.44 & 2.75 & $0.040^{*}$ \\
\hline 21.Work requirements & $2.00^{\text {bdefg }}$ & $2.97^{\mathrm{ac}}$ & $3.27^{\mathrm{a}}$ & $2.72^{\text {acef }}$ & $2.75^{\text {ace }}$ & $0.002^{* *}$ \\
\hline 24.Haven't been there, so I want to go & $2.75^{\text {acdef }}$ & $3.47^{\mathrm{ab}}$ & $3.27^{\mathrm{abd}}$ & $3.61^{\mathrm{a}}$ & $3.25^{\text {abde }}$ & $0.037^{*}$ \\
\hline $\begin{array}{l}\text { 29.Communications between the same } \\
\text { industry }\end{array}$ & $2.55^{\text {bcdef }}$ & $3.37^{\mathrm{a}}$ & $3.27^{\mathrm{ac}}$ & $2.83^{\text {acde }}$ & $3.25^{\text {acd }}$ & $0.017^{*}$ \\
\hline $\begin{array}{l}\text { 30.Satisfy the spiritual needs of seeking } \\
\text { new and different ideas }\end{array}$ & 3.10 & 3.77 & 3.27 & 3.33 & 4.00 & $0.026^{*}$ \\
\hline
\end{tabular}

Remark. "*" indicates significant difference. "**" shows that the difference is extremely significant.

Table 6. Differences in motivation between subjects with different academic background

\begin{tabular}{|c|c|c|c|c|c|c|c|}
\hline Motivations & $\begin{array}{l}\text { Junior high } \\
\text { school and } \\
\text { below (mean) }\end{array}$ & $\begin{array}{l}\text { High school and } \\
\text { secondary school } \\
\text { (mean) }\end{array}$ & $\begin{array}{l}\text { College } \\
\text { (mean) }\end{array}$ & $\begin{array}{c}\text { Bachelor } \\
\text { (mean) }\end{array}$ & $\begin{array}{l}\text { Master } \\
\text { (mean) }\end{array}$ & $\begin{array}{l}\text { Doctor } \\
\text { (mean) }\end{array}$ & Sig. \\
\hline 6.Share experience after the tour & $4.00^{\mathrm{ac}}$ & $4.22^{\mathrm{a}}$ & $3.69^{\text {acdfh }}$ & $3.81^{\text {acdf }}$ & $4.00^{\text {acd }}$ & $2.17^{\text {bcegij }}$ & $0.009^{* *}$ \\
\hline 8.Recommended by others & $3.00^{\text {acegh }}$ & $3.22^{\text {aceg }}$ & $3.33^{\text {ace }}$ & $3.48^{\mathrm{ac}}$ & $3.65^{\mathrm{a}}$ & $2.00^{\text {bdfghi }}$ & $0.017^{*}$ \\
\hline 9.Seeking excitement & $4.00^{\mathrm{a}}$ & $3.78^{\mathrm{ab}}$ & $3.49^{\text {abceg }}$ & $3.61^{\text {abce }}$ & $3.71^{\mathrm{abc}}$ & $1.83^{\text {abdfhi }}$ & $0.045^{*}$ \\
\hline $\begin{array}{l}\text { 11. Related to the field of your } \\
\text { own research }\end{array}$ & 3.50 & 3.33 & 2.73 & 2.95 & 3.41 & 1.83 & $0.044^{*}$ \\
\hline 13.Try new things & $3.50^{\text {acegi }}$ & $4.00^{\mathrm{ac}}$ & $3.51^{\text {aceg }}$ & $3.80^{\text {ace }}$ & $4.24^{\mathrm{a}}$ & $1.50^{\text {bdfhij }}$ & $0.000^{* *}$ \\
\hline 17.Satisfy your own curiosity & 4.50 & 3.78 & 3.49 & 3.80 & 3.76 & 2.33 & $0.040^{*}$ \\
\hline
\end{tabular}

Remark. "*" indicates significant difference. "**" shows that the difference is extremely significant.

Table 7. Differences in motivation between subjects from different occupations

\begin{tabular}{lcccc}
\hline \multicolumn{1}{c}{ Occupations } & $\begin{array}{c}\text { 3. Expand the } \\
\text { horizons }\end{array}$ & $\begin{array}{c}\text { 10.Investigate } \\
\text { advanced } \\
\text { technology }\end{array}$ & $\begin{array}{c}\text { 16.Education for } \\
\text { children in science } \\
\text { and technology }\end{array}$ & $\begin{array}{c}\text { 29.Communications } \\
\text { between the same } \\
\text { industry }\end{array}$ \\
\hline Merchant(mean) & 4.31 & 3.88 & 4.25 & 3.88 \\
Civil servant(mean) & 3.40 & 2.80 & 2.80 & 2.80 \\
Teacher(mean) & 3.93 & 2.93 & 4.13 & 2.80 \\
Senior white-collar worker(mean) & 4.29 & 3.71 & 4.29 & 4.14 \\
General white-collar worker (mean) & 4.34 & 3.44 & 3.69 & 3.28 \\
Military(mean) & 5.00 & 5.00 & 4.00 & 1.00 \\
Blue-collar workers(mean) & 1.00 & 1.00 & 1.00 & 0.00 \\
Retired employees & 0.00 & 0.00 & 0.00 & 3.23 \\
Students(mean) & 3.90 & 3.21 & 3.51 & 3.20 \\
Unemployed(mean) & 3.40 & 2.60 & 4.00 & 3.50 \\
Scientific researchers(mean) & 4.25 & 3.00 & 3.75 & 3.57 \\
Others(mean) & 3.57 & 3.14 & 3.71 & $0.031^{*}$ \\
Sig. & $0.029^{*}$ & $0.043^{*}$ & $0.016^{*}$ & \\
\hline
\end{tabular}

Remark. "*" indicates significant difference. "**" shows that the difference is extremely significant. 


\subsubsection{Differences in motivation between subjects of different genders}

Subjects of different genders differed in the four motivations shown in Table 8.

Table 8. Differences in motivation between subjects of different genders

\begin{tabular}{lccc}
\hline \multicolumn{1}{c}{ Motivations } & Male(mean) & Female(mean) & Sig. \\
\hline 4.Attracted by advertising & 2.95 & 3.24 & $0.010^{*}$ \\
7.Follow others & 2.65 & 2.84 & $0.027^{*}$ \\
10.Investigate advanced technology & 3.41 & 3.13 & $0.023^{*}$ \\
23.Want to understand the future direction of technology & 3.68 & 3.35 & $0.002^{* *}$ \\
\hline
\end{tabular}

Remark. "*" indicates significant difference. "**" shows that the difference is extremely significant.

\subsubsection{Pairwise comparison}

After comparing the data reflecting these differences, the results show that the group of " 19 years old and below" have differences with "20-29 years old" and "40-49 years old" in "Education for children in science and technology". There are also differences between "19 years old and below" and "20-29 years old" in "work requirements", "communications between the same industry" and "Haven't been there, so I want to go". subjects with doctoral degrees have differences in several motivations compared with subjects from other education background. There is no difference in the group of monthly income and the group of occupations. In Tables 5 and 6 , the author has labeled the data which has differences.

\section{$5 \quad$ Discussion}

The results of the study show that more than $80 \%$ of the 281 effective subjects expressed a clear preference for science and technology tourism. This means that although the development of science and technology tourism has not yet reached a mature stage, the potential and the existing market has a certain scale. In the interview, I also learned that some travel agencies are not willing to build such a tourism product because they feel that there is no market and it is difficult to make a profit. After examining the question of whether different subjects have different attitudes toward science and technology tourism, we found that tourists of different genders, ages, education, occupations, and incomes have no significant differences in attitude toward science and technology tourism. which is very different from my previous assumptions. This also means that travel agencies can design more technology travel products for different market segments.

Among the five types of science and technology travel, the subjects' favorite is "natural science and ecological tour", followed by "technology theme park tour", and the most inattentive to subjects was "industrial tour". As a travel agency, it is necessary to make full use of existing tourism resources, such as geological resources and astronomical resources, to explore the value of natural resources in depth. These resources are constant, but their value is variable. The variability lies in the process of discovering the connotation of science and technology and the value presented to tourists.

According to Zhang Weihong's research, "Mental relaxation is the first among all motives. Relaxation is still the most important tourist motivation". But results show that most subjects want to seek more fresh experience. Therefore, it is obvious that relaxation is the main motivation for primary tourism and holiday tourists, and for science and technology tourists, pursuing a fresh experience and gaining new experience is the main motivation, which also proves that technology tourists are different from mass tourists. This also shows that the essence of tourism is to find differences. During the tour, they get different feelings away from their usual life and pursue a fresh sense. This proves that cross-border knowledge is of value. The difference between the knowledge reserves owned by tourists and the knowledge that technology tourism can provide determines the commercial value of technology tourism. As long as it has value, it means there is a market.

Scientific tourism enables visitors to increase their own experience while enriching their own curiosity, enriching their knowledge and forming new ideas. Whether it is a different technology tourism destination or a different specific technology tourism activity, we must focus on creating a unique tourism product that conveys a fun, differentiated knowledge experience rather than a popular tourist route. 
What the subjects did not pay attention to was to "Follow others". The consumption of technology tourists is rational and non-blind. In product packaging and promotion, we avoid using inflammatory, savvy language.

In the identification of motivation, the results showed that the "19 years old and below" group had significantly higher motivations in "seeking excitement" and "satisfying their own curiosity" than other age groups. This is in line with previous research by Pearce \& Lee (2005), who believes that motivations such as excitement and reputation are more important for tourists with less travel experience. Young tourists are more interested in stimulating and curious tourism activities due to lack of tourism experience. Therefore, when designing and building products for this market, we must emphasize the novelty and also need some stimulating and participatory interaction.

There is no difference in motivation in the group of monthly income and the group of occupations. Therefore, in the product design and marketing language, it is necessary to emphasize the motives that subjects generally agree with, such as broadening their horizons and increasing their experience and ideas.

After a pairwise comparison, we found that subjects with doctoral degrees or above differed from other educational backgrounds in identifying some motivations. Although the subjects with $\mathrm{Ph}$. D. and above also expressed their preference for science and technology travel, the recognition of travel motivation is lower than that of other groups. This may be due to the fact that highly educated tourists cannot experience differences and freshness in science and technology tourism. Therefore, as far as our research results are concerned, the higher-educated population may not be the target market for technology tourism.

\section{Conclusion}

The conclusions of this paper can be summarized into four points:

Firstly, most of the subjects like technology tourism, which means that the market for science and technology tourism is very extensive and needs to be explored. Travel agencies should not take it for granted that there is no market for science and technology tourism, it is not worth investing in manpower and material resources, they should conduct market inspections, and then design tourism products according to customer needs.

Secondly, by comparing with the tourism motives of mass tourists, we find that science and technology tourism is a high-end form of tourism. Travel agencies should focus on people who have experienced tourism and have experienced leisure vacations many times.

Thirdly, cross-border knowledge has high commercial value. When designing and developing products, we had better pay attention to integrating scientific knowledge into the whole travel itinerary. It is not necessary to attract tourists with unique destinations or unique activities. Instead, we must dig a lot of knowledge-based products.

Fourthly, the demographic difference of travel motivation is not obvious, which shows that there is no clear market segmentation. Everyone chooses technology tourism for the novel experience. Therefore, when designing, marketing and selling products, we must emphasize the location, the content of the activity and the novelty of the knowledge conveyed.

\section{$7 \quad$ Inadequacies}

Although this paper has obtained some conclusions in the research process, there are still limitations. First, most of the subjects are college students, so the answer may have a certain tendency. Secondly, the questionnaires are distributed online and cannot guarantee the authenticity of the answers. Again, due to the time relationship, in-depth interviews have only been conducted three times, and should be discussed with more subjects to listen to their views. Finally, due to the author's own reasons, there may be personal bias in the analysis and discussion of the results. If conditions permitting, I believe that if more subjects will be involved, and the results will certainly have more implications for the future development of technology tourism and the development of travel agency products. 


\section{References}

1. Iso-Ahola S E. Toward a social psychological theory of tourism motivation: A rejoinder[J]. Annals of Tourism Research, 1982, 9(2):256-262.

2. Kozak M. Comparative analysis of tourist motivations by nationality and destinations[J]. Tourism Management, 2002, 23(3):221-232.

3. Zhang Hongmei, Lu Lin. A Review of Foreign Tourism Motivations in Recent 10 Years[J]. Area Research and Development, 2005, 24(2): 60-64.

4. LIU Xiao, GAN Zhimao, YANG Yanfeng. Tourism Motivation-Return of Human Nature - A New Discussion on Tourism Motivation[J]. Journal of Arid Land Resources and Environment, 2006, 20(1): 33-36.

5. ZHAO Wei, GUAN Hongzhi, WANG Wei. Analysis of Tourism Destination Choice Behavior Based on Tourism Motivation[J]. Journal of Transportation Systems Engineering and , 2014, 14(5): 175-180.

6. Guo Anzhen, Huang Fucai. Research on the Relationship between Tourism Motivation, Satisfaction, Trust and Revisiting Intention[J]. Journal of Zhejiang Gongshang University, 2013, 1(1):78-87.

7. Kozak M. Comparative analysis of tourist motivations by nationality and destinations[J]. Tourism Management, 2002, 23(3):221-232

8. Kraftchick J F, Byrd E T, Canziani B, et al. Understanding beer tourist motivation[J]. Tourism Management Perspectives, 2014, 12(12):41-47.

9. Zhang Tao. Research on the Influence of Dietary Travel Motivation on Tourist Satisfaction and Behavioral Intention[J]. TOURISM TRIBUNE, 2012, 27(10):78-84.

10. Jing X, Chan S M. A new nature-based tourism motivation model: testing the moderating effects of the push motivation.[J]. Tourism Management Perspectives, 2016, 18:107-110.

11. Bian X, Wang H, Shi L. Rural Residents' Tourism Motivation and Influence on Choice of Tourism Destination Classification:A Case of the Changjiang River Delta Region[J]. Scientia Geographica Sinica, 2016, 36(1):99-106.

12. Jaapar M, Musa G, Moghavvemi S, et al. Dental tourism: Examining tourist profiles, motivation and satisfaction[J]. Tourism Management, 2017, 61:538-552. 